\title{
PENGARUH KEPEMIMPINAN DAN KOMPENSASI TERHADAP KINERJA KARYAWAN \\ (Studi Kasus Pekerja Proyek Pada PT. ARILUM)
}

\author{
Muhamad Ridwan ${ }^{1)}$
}

email : ridwan arsitek@yahoo.com

ARTICLES

INFORMATION

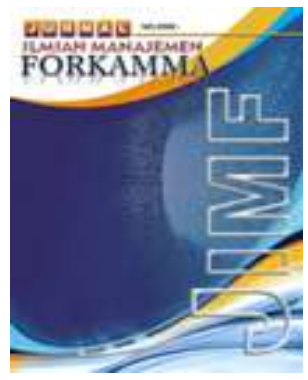

JURNAL ILMIAH MANAJEMEN FORKAMMA

\author{
Vol.1, No.3, Mei 2018 \\ Halaman : $97-109$ \\ (c) LPPM \& FORKAMMA
}

Prodi Magister Manajemen

UNVERSITAS PAMULANG

$$
\begin{array}{cc}
\text { ISSN (online) } & : 2599-171 X \\
\text { ISSN (print) } & : 2598-9545
\end{array}
$$

\section{Keyword :}

leadership.compensation. employee performance

JEL. classification : C33, G20, G23, N65

\section{Contact Author :}

PRODI
MAGISTER MANAJEMEN \&
FORKAMMA UNPAM
JL.Surya Kencana No.1 Pamulang
Tangerang Selatan - Banten
Telp. (021) 7412566, Fax (021) 7412491
Email :
uurnalforkamma.unpam@gmail.com

Tujuan penelitian ini adalah untuk mengetahui Pengaruh kepemimpinan dan Kompensasi terhadap Kinerja Karyawan. Penelitian ini dilakukan terhadap pekerja proyek PT. Airtas Rekacipta lluminasi. Penelitian ini menggunakan metode kuantitatif dengan teknik survei. Instrumen pengumpul data yang digunakan adalah kuesioner tertutup dengan skala likert dengan jumlah populasi sebanyak 70 orang pekerja proyek, dengan sampel responden sebanyak 60 orang pekerja proyek PT. Airtas Rekacipta lluminasi. Teknik analisis yang digunakan adalah Uji validitas, Uji reliabilitas, Uji Heteroskedastisitas, Uji Multikolinearitas, Uji determinasi, Pengujian Hipotesis menggunakan Model Regresi sederhana dan Berganda ,Uji t dan Uji f. Data dianalisis dengan menggunakan metode statistik dengan program SPSS. Hasil dari penelitian ini menunjukkan bahwa terdapat pengaruh Kepemimpinan terhadap Kinerja Karyawan dengan kontribusi sebesar 83,3\%, terdapat pengaruh Kompensasi terhadap Kinerja Karyawan dengan kontribusi sebesar $78.7 \%$, terdapat pengaruh Kepemimpinan dan Kompensasi secra bersama-sama terhadap Kinerja.

The objective of this research are to know about the influence of the leadership and compensation to employee performance. This research was conducted to PT. Airtas Rekacipta lluminasi project workers. This study used quantitative methods with survey. Data collecting instrument used was a questionnaire with likert scale with 70 people of population on the project employee, with the sample of respondents as much as 60 people of PT. Airtas Rekacipta Iluminasi workers. Analytical techniques is used obiter Validity Test, Reliability Test, Heteroskedastisitas Test, Multicollinearity Test, Determination Test, Hypothesis Testing using Simple And Double Regression Model, $t$-Test, and $f$-Test. The research data were analyzed using statistical methods with the program SPSS. The results of this research show that: There is a influence between The Leadershipnagainst employee performance, there is a influence between The Compensation against employee performance, There is a influence simultaneously between Leadership and Compensation against employee Performance. (Y). Positive regression coefficient obtained Leadership 


\section{A. Pendahuluan}

Saat ini sektor investasi yang sedang berkembang pesat di Indonesia adalah di sektor properti. Indonesia masih menjadi negara tujuan untuk investasi di bidang properti. Hal itu terlihat dari banyaknya investor dari negara lain yang berminat menanamkan modalnya dalam bidang properti di negara ini. Geliat pertumbuhan investasi di sektor properti tidak hanya terjadi di Jabodetabek saja., tetapi juga sudah merambah ke berbagai daerah-daerah diluar pulau Jawa, seperti Riau, lampung, Kalimantan, dan daerah-daerah lainnya di Negara Indonesia.

Potensi usaha di bidang arsitektur, jasa konstruksi dan properti sangat berperan dalam kegiatan perekonomian, khususnya dalam kegiatan pembangunan. Dengan adanya industri jasa konstruksi, akan memberikan peluang yang besar bagi penyerapan tenaga kerja yang memiliki keahlian dibidang industri jasa dibidang arsitektur, konstruksi dan bangunan. Dengan tersedianya lapangan pekerjaan, maka akan menciptakan pendapatan bagi tenaga kerja dan mengurangi tingkat pengangguran. Fenomena seperti ini menyebabkan kebutuhan akan tenaga kerja di bidang arsitektur, bangunan dan properti sangat tinggi, tertutama untuk pekerja proyek. Perkembangan Pendidikan formal yang semakin membaik, menyebabkan semakin berkurangnya minat sumber daya manusia untuk menjadi pekerja proyek, karena dengan pendidikan formal yang baik mereka akan memilih pekerjaan yang dianggap lebih baik dan tidak mengeluarkan tenaga yang cukup besar.

Saat ini sektor investasi yang sedang berkembang pesat di Indonesia adalah di sektor properti. Indonesia masih menjadi negara tujuan untuk investasi di bidang properti. $\mathrm{Hal}$ itu terlihat dari banyaknya investor dari negara lain yang berminat menanamkan modalnya dalam bidang properti di negara ini. Geliat pertumbuhan investasi di sektor properti tidak hanya terjadi di Jabodetabek saja., tetapi juga sudah merambah ke berbagai daerah-daerah diluar pulau Jawa, seperti Riau, lampung, Kalimantan, dan daerah-daerah lainnya di Negara Indonesia.

Potensi usaha di bidang arsitektur, jasa konstruksi dan properti sangat berperan dalam kegiatan perekonomian, khususnya dalam kegiatan pembangunan. Dengan adanya industri jasa konstruksi, akan memberikan peluang yang besar bagi penyerapan tenaga kerja yang memiliki keahlian dibidang industri jasa dibidang arsitektur, konstruksi dan bangunan. Dengan tersedianya lapangan pekerjaan, maka akan menciptakan pendapatan bagi tenaga kerja dan mengurangi tingkat pengangguran. Fenomena seperti ini menyebabkan kebutuhan akan tenaga kerja di bidang arsitektur, bangunan dan properti sangat tinggi, tertutama untuk pekerja proyek. Perkembangan Pendidikan formal yang semakin membaik, menyebabkan semakin berkurangnya minat sumber daya manusia untuk menjadi pekerja proyek, karena dengan pendidikan formal yang baik mereka akan memilih pekerjaan yang dianggap lebih baik dan tidak mengeluarkan tenaga yang cukup besar.

Strategi mengelola SDM yang baik sangat diperlukan dalam mempertahankan sumber daya yang ada yang dimiliki perusahaan, salah satunya adalah strategi kepemimpinan dan kompensasi. Apabila dalam suatu perusahaan tercipta kesenjangan antara pimpinan dan bawahannya, maka akan timbul rasa tidak nyaman yang mana nantinya akan mempengaruhi kinerja karyawan. Salah satu permasalahan yang terjadi kondisi keberhasilan suatu proyek ditentukan oleh kepemimpinan dan kompensasi yang diberikan.

Berdasarkan observasi awal, permasalahan yang terjadi di PT. Arilum adalah adalah pemimpin harus selalu mengawasi pekerja atau karyawan, apabila tidak dilakukan pengawasan maka kinerja karyawan menurun, bahkan terkadang untuk sebagian pekerja, walau sudah dilakukan pengawasan kinerja masih tetap tidak mencapai hasil yang 
diinginkan perusahaan, terkadang pemimpin sulit mengambil sikap karena keterbatasan pekerja proyek di lapangan.

Sistem pemberian Kompensasi berupa gaji yang dirasa cukup dan layak serta bonus atas prestasi sudah diterapkan, namun karena saat ini mudahnya mereka (pekerja proyek) mendapatkan pekerjaan menyebabkan fungsi kompensasi seakan tidak bisa efektif meningkatkan kinerja kerja para pekerja proyek.

Berdasarkan uraian tersebut di atas Peneliti tertarik untuk melakukan penelitian dengan judul "Pengaruh Kepemimpinan dan Kompensasi Terhadap Kinerja Karyawan ( Studi Kasus Pekerja Proyek Pada PT. ARILUM )".

\section{B. Perumusan Masalah}

Berdasarkan latar belakang yang telah diungkapkan di atas, maka rumusan masalah dalam penelitian ini adalah :

1. Apakah kepemimpinan berpengaruh signifikan terhadap kinerja Karyawan PT. ARILUM ?

2. Apakah Kompensasi berpengaruh signifikan terhadap kinerja Karyawan PT. ARILUM ?

3. Apakah Kepemimpinan dan Kompensasi secara simultan berpengaruh signifikan terhadap kinerja Karyawan PT. ARILUM ?

C. Kerangka Berpikir

Kerangka berfikir penelitian ini dapat digambarkan sebagai berikut:

\section{PENGARUH KEPEMIMPINAN DAN KOMPENSASI TERHADAP KINERJA KARYAWAN ( STUDI KASUS PEKERJA PROYEK PADA PT. ARILUM )}

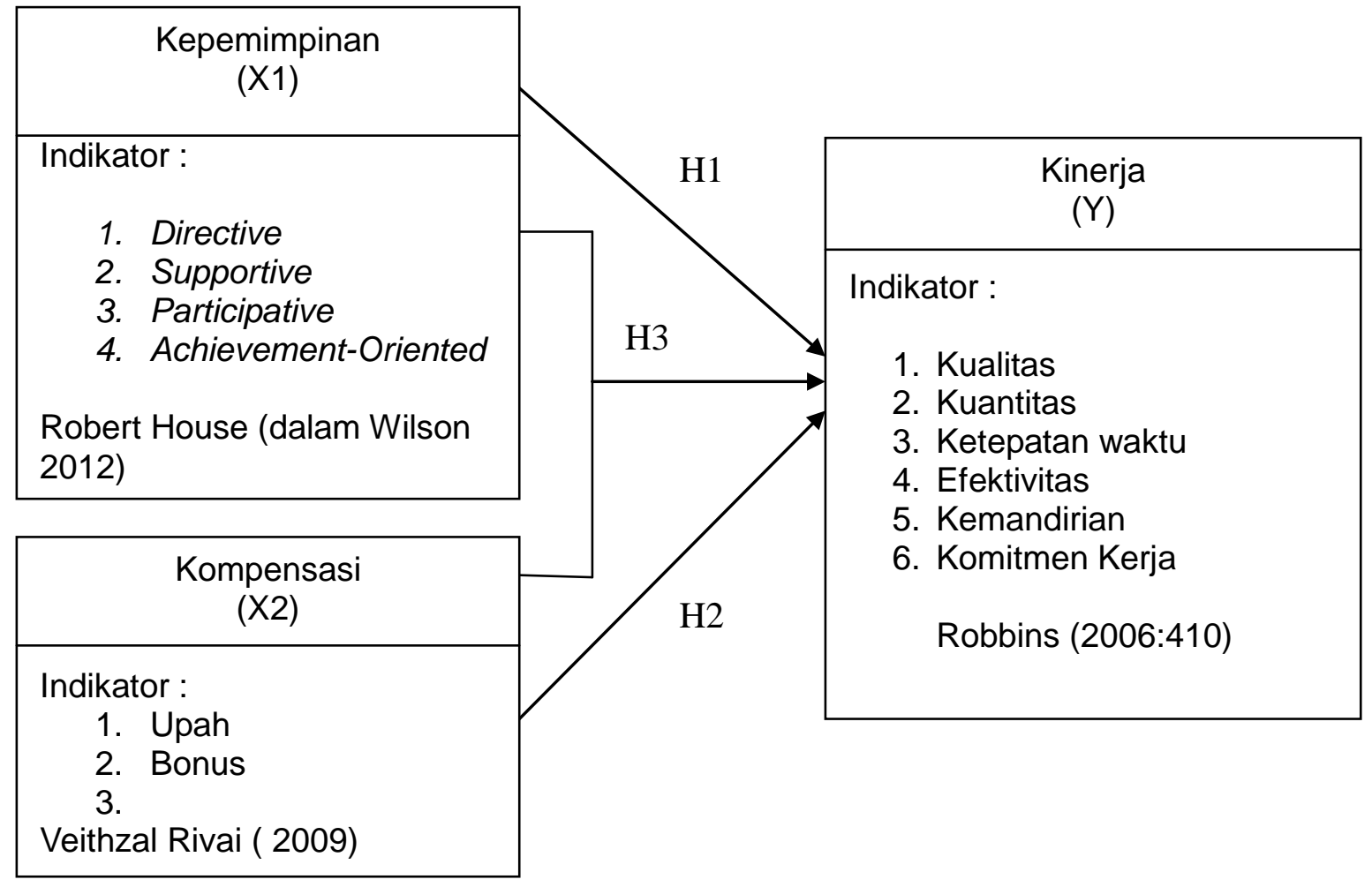

Gambar. 1.1

Kerangka Berpikir 


\section{Landasan Teori}

\section{Kepemimpinan}

Menurut Malayu Hasibuan (2006:170) kepemipinan adalah cara seorang pemimpin mempengaruhi perilaku bawahan, agar mau bekerja sama dan bekerja secara produktif untuk mencapai tujuan organisasi. Robins (2006) mendefinisikan bahwa kepemimpinan sebagai kemampuan untuk mempengaruhi kelompok dalam mencapai tujuan organisasi.

\section{Kompensasi}

Kompensasi menurut Veithzal Rivai (2009) merupakan sesuatu yang diterima karyawan sebagai pengganti kontribusi jasa mereka pada perusahaan. kompensasi merupakan jumlah paket yang ditawarkan organisasi kepada pekerja sebagai imbalan atas penggunaan tenaga kerjanya (Wibowo, 2007).

\section{Kinerja}

Menurut Mangkunegara (2009:67) kinerja adalah hasil kerja secara kualitas dan kuantitas yang dicapai oleh seorang pegawai dalam melaksanakan tugasnya sesuai dengan tanggung jawab yang diberikan kepadanya. Kinerja karyawan adalah yang mempengaruhi seberapa banyak/besar mereka member kontribusi organisasi (rivai dan basri, 2005 :14). Menurut Robbins (2006:410) kinerja adalah "Performance, how well you do please of work and activity". Pengertian menunjukan bahwa kinerja terlihat dari aktivitas seseorang dalam melaksanakan pekerjaan, aktivitas ini menggambarkan bagaimana seseorang berusaha dalam mencapai tujuan yang telah ditetapkan dan juga merupakan hasil evaluasi terhadap pekerjaan yang dilakukan dibandingkan dengan kriteria yang telah ditetapkan bersama.

\section{E. Metodologi Penelitian}

Metode penelitian yang digunakan dalam penelitian ini adalah metode penelitian kuantitatif. Metode ini menggunakan data penelitian berupa angka-angka dan analisis menggunakan statistik, dengan tujuan untuk mengiji hipotesis yang telah ditetapkan.

\section{Populasi Dan Sampel}

a) Populasi

Menurut Sugiyono (2010 : 115), populasi adalah wilayah generalisasi yang terdiri dari obyek atau subyek yang mempunyai kuantitas dan karakteristik tertentu yang ditetapkan oleh peneliti untuk dipelajari dan kemudian ditarik kesimpulannya. Pada Penelitian ini Populasi yang digunakan adalah pekerja proyek PT. Arilum yang berjumlah 60 orang.

b) Sampel

Dalam penelitian ini, peneliti melakukan penarikan sampel penelitian dengan cara simple random sampling (sampling acak sederhana) dimana sampel dipilih secara acak dari jumlah yang telah ditentukan, yang berarti semua anggota populasi memiliki kesempatan yang sama untuk menjadi subyek penelitian. DAlam penelitian ini seluruh populasi dijadikan sebagai sampel, yaitu sebanyak 60 orang.

\section{Analisis Data}

Analisis data Analisis data yang digunakan dalam penelitian ini adalah uji validitas dan uji reliabilitas. Pengujian validitas menggunakan rumus korelasi pearson product moment, dengan ketentuan jika hiung $r>$ tabel $r$, berarti instrumen valid. Pengujian 
reliabilitas dalam penelitian ini menggunakan nilai Alpha Coanbach dengan ketentuan jika Alpha Croanbach ( hitung $r$ ) $>0,60$ berarti instrumen tersebut reliabel. Teknik analsis data antara lain uji asumsi klasik dan analisis regresi ganda. Uji asumsi klasik terdiri dari uji normalitas, uji multikolinearitas, uji heteroskedastisitas.

\section{Uji Normalitas}

Data yang telah terkumpul harus diuji normalitasnya terlebih dahulu guna mengetahui apakah data penelitian berasal dari populasi yang sebarannya normal atau tidak. Pengujian normalitas menggunakan One-sample Kolmogorov-Smirnov Test dengan SPSS 17.0 for windows. Dengan ketentuan, jika nilai Asymp Sig > 0,05 maka data berdistribusi normal.

\section{Uji Multikolinearitas}

Uji Multikolinearitas dilakukan untuk mengetahui ada tidaknya kemiripan yang dimiliki oleh satu variabel independent dengan variabel independen yang lain dalam satu model. Pengujian multikolinearitas dalam penelitian ini menngunakan VIF (Variance Inflation Factor), dengan ketentuan jika nilai tolerance $>0,1$ dan nilai VIF $<10$, maka data tidak maka data tidak mengalami multikolinearitas.

\section{Uji Heterokedastisitas}

Pengujian dilakukan untuk mengetahui apakah terjadi penyimpangan model karena gangguan variabel yang berbeda antar observasi ke observasi lain. Untuk mengetahui apakah terjadi heteroskedastisitas atau tidak, dapat dilihat pada gambar Scattreplot, jika pada gambar scatterplot tidak ada pola yang jelas serta titiktitik menyebar diatas dan dibawah angka 0 pada sumbu Y, maka tidak terjadi heterokedastisistas.

\section{Analisis Regresi Ganda}

Teknik analisis regresi ganda dipergunakan untuk mengetahui pengaruh kepemimpinan dan Kompensasi terhadap kinerja Karyawan PT. ARILUM. Dengan persamaan regresi $Y=a+b_{1} X_{1}+X_{2} b_{2}$

Teknik pengujian hipotesis menggunakan uji parsial dan uji simultan dengan teknik probabilitas, dengan cara membandingkan nilai probabilitas Sig dengan taraf signifikansi 0,05 . Jika nilai probabilitas sig $<0,05$ maka signifikan.

\section{Koefisien Determinasi}

Pengujian koefisien determinasi bertujuan untuk mengetahui besarnya pengaruh antar variabel. Nilai koefisien determinasi menunjukkan presentase variasi nilai variabel dependen yang dapat dijelaskan oleh persamaan regresi yang dihasilkan.

\section{F. Hasil Analisis Data dan Hasil Penelitian}

\section{Uji Validitas dan Uji Reliablitas}

Hasil uji validitas dengan menggunakan rumus korelasi product moment dan membandingkan dengan $r$ tabel dengan taraf siginfikansi sebsar $5 \%$ maka diperoleh $r$ tabel yaitu 0,254 sehingga berikut ini hasil intrumen kusiner no 1 untuk setiap variabel diperoleh nilai:

a. Kepemimpinan, instrument kuisioner no 1 diperoleh nilai $r$ hitung $(0,682)>$ tabel $(0,254)$ sehingga instrument no 1 dikatakan valid.

b. Kompensasi, instrument kuisioner no 1 diperoleh nilai $r_{\text {hitung }}(0,522)>r_{\text {tabel }}(0,254)$ sehingga instrument no 1 dikatakan valid.

c. Kinerja, instrument kuisioner no 1 diperoleh nilai $r$ hitung $(0,422)>r_{\text {tabel }}(0,254)$ sehingga instrument no 1 dikatakan valid. 


\section{JUTNAL

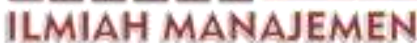 \\ ISSN (print) : 2598-9545 \& ISSN (online) : 2599-171X \\ FORKAMMA}

Setelah dilaukan uji validitas dan seluruh intrumen di nyatakan valid, maka tahap selanjut nya adlaah uji reliabilitas dimana $r$ ca di bandingkan dengan $r$ tabel pada setiap variabel kuisioner nya:

a. Kepemimpinan, memperoleh nilai $r_{\text {ca }}(0,859)>0,600$ sehingga kusioner variabel Kepemimpinan dikatakan reliabel.

b. Kompensasi, memperoleh nilai $r_{\text {ca }}(0,893)>0,600$ sehingga kusioner variabel Kompensasi dikatakan reliabel

c. Kinerja, memperoleh nilai $r_{\text {ca }}(0,852>$ tabel $(0,198)$ sehingga kusioner variabel Kinerja dikatakan reliabel

\section{Uji Asumsi Klasik}

\section{Uji Multikolinearitas}

Pengujian ada tidaknya gejala multikolinieritas dilakukan dengan mempertahankan nilai matriks korelasi yang dihasilkan pada saat pengolahan data serta nilai VIF (Variance Inflation Factor) dan tolerance sebagai berikut:

Tabel. 1.1 Uji Multikolinearitas

Coefficients $^{\mathrm{a}}$

\begin{tabular}{|c|c|c|c|c|c|c|c|c|}
\hline \multirow{2}{*}{\multicolumn{2}{|c|}{ Model }} & \multicolumn{2}{|c|}{$\begin{array}{l}\text { Unstandardized } \\
\text { Coefficients }\end{array}$} & \multirow{2}{*}{\begin{tabular}{|c|}
$\begin{array}{c}\text { Standardized } \\
\text { Coefficients }\end{array}$ \\
Beta
\end{tabular}} & \multirow[b]{2}{*}{$\mathrm{t}$} & \multirow[b]{2}{*}{ Sig. } & \multicolumn{2}{|c|}{ Collinearity Statistics } \\
\hline & & B & Std. Error & & & & Tolerance & VIF \\
\hline & (Constant) & 2.721 & 2.667 & & 1.020 & .312 & & \\
\hline & kompensasi & .326 & .124 & .328 & 2.636 & .011 & .169 & 5.930 \\
\hline & kepemimpinan & .619 & .126 & .613 & 4.922 & .000 & .169 & 5.930 \\
\hline
\end{tabular}

a. Dependent Variable: kinerja

\section{Sumber: Hasil Olah Data Penelitian}

Berdasarkan tabel diatas maka diperoleh nilai tolerance value variabel Kepemimpinan 0,169 $>0,10$ dan sedangkan VIF nya 5,930<10,00 lalu nilai tolerance value variabel Kompensasi diperoleh nilai $0,169>0,10$ sedangkan VIF nya diperoleh nilai $5,930>0,10$ sehingga data tersebtu tidak terjadi multikolinearitas.

\section{Uji Normalitas}

Uji Normalitas bertujuan menguji apakah model regresi, variabel dependen dan independen keduanya memiliki distribusi normal atau tidak. Uji normalitas dapat dilihat dari nilia Asym.sig pata tabel One Sample Kolmogrov Smirnov Test:

Tabel 1.2 Uji Normalitas

One-Sample Kolmogorov-Smirnov Test

\begin{tabular}{|ll|r|r|r|}
\hline & & kinerja & Kompensasi & kepemimpinan \\
\hline N & & 60 & 60 & 60 \\
& Mean & 50.0000 & 50.0000 & 50.0000 \\
Most Extreme Differences & Std. Deviation & 9.46791 & 9.52444 & 9.37522 \\
& Positive & .116 & .157 & .162 \\
& Negative & .109 & .157 & .162 \\
& & -.116 & -.112 & -.102 \\
Kolmogorov-Smirnov Z & & .901 & 1.213 & 1.251 \\
Asymp. Sig. (2-tailed) & & .391 & .105 & .087 \\
\hline
\end{tabular}

a. Test distribution is Normal.

Sumber: Hasil Olah Data Penelitian 
Dari tabel diatas maka diperoleh nilai Asym Sig 2 tailed Kinerja 0,391 > 0,05, Kompensasi 0,105 > 0,05, dan Kepemimpinan 0,987 > 0,05 sehingga data tersebut berdistribusi normal.

\section{Uji Heteroskedastisitas}

Dari scatterplot tersebut, terlihat bahwa titik-titik menyebar secara acak, baik di bagian atas angka 0 atau bagian bawah angka 0 dari sumbu vertikal atau sumbu $Y$. Dengan demikian dapat disimpulkan bahwa tidak terjadi heteroskedastisitas dalam model regresi ini.

Scatterplot

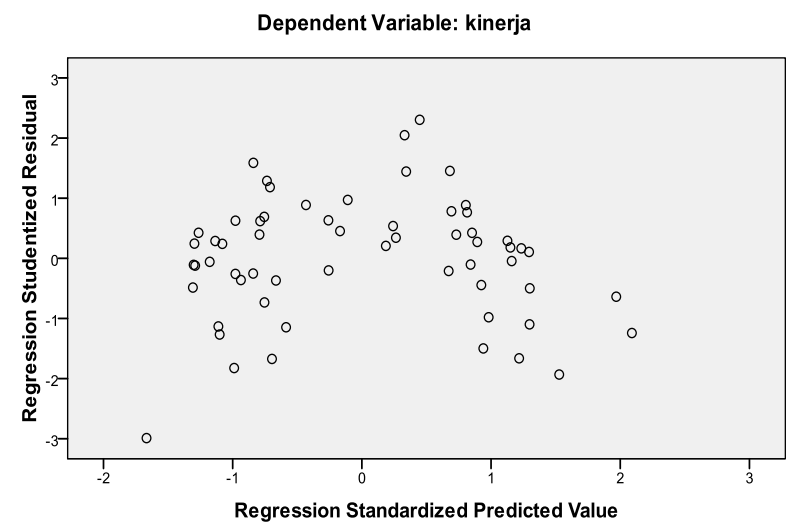

Gambar 1.2 Scatter Plot

\section{Analisi Regresi Linear Berganda}

Tabel 1.3 Analsis Regresi Linear Berganda

\begin{tabular}{|c|c|c|c|c|c|c|}
\hline \multicolumn{7}{|c|}{ Coefficients $^{a}$} \\
\hline \multirow{2}{*}{\multicolumn{2}{|c|}{ Model }} & \multicolumn{2}{|c|}{ Unstandardized Coefficients } & \multirow{2}{*}{$\begin{array}{c}\begin{array}{c}\text { Standardized } \\
\text { Coefficients }\end{array} \\
\text { Beta }\end{array}$} & \multirow[b]{2}{*}{$\mathrm{t}$} & \multirow[b]{2}{*}{ Sig. } \\
\hline & & $\mathrm{B}$ & Std. Error & & & \\
\hline 1 & (Constant) & 2.721 & 2.667 & & 1.020 & .312 \\
\hline & kompensasi & .326 & .124 & .328 & 2.636 & .011 \\
\hline & kepemimpinan & .619 & .126 & .613 & 4.922 & .000 \\
\hline
\end{tabular}

a. Dependent Variable: kinerja

\section{Sumber: Hasil Olah Data Penelitian}

Persamaan Regresi linear berganda $Y=2,721+0,619 X 1+0,326 X 2$ Dapat dijelaskan sebagai berikut :

1. Nilai konstanta intersep sebesar 2,721 merupakan nilai konstanta (a)

2. Nilai koefisien regresi variabel kepemimpinan terhadap kinerja adalah sebesar 0,619 . Hal ini berarti jika variabel kepemimpinan naik 1 satuan akan meningkat variabel kinerja sebesar 0,619 , dengan asumsi variabel kompensasi dianggap konstan. 
3. Nilai koefisien regresi variabel kompensasi terhadap kinerja adalah sebesar 0,326. Hal ini berarti jika variabel kompensasi naik 1 satuan akan meningkat variabel kinerja sebesar 0,326, dengan asumsi variabel kepemimpinan dianggap konstan.

4. Karena Nilai Koefisien regresi kepemimpinan dan kompensasi bernilai positif, maka menunjukan ada pengaruh kepemimpinan dan Kompensasi secara bersama-sama terhadap kinerja karyawan.

Koefisiensi determinasi $\left(R^{2}\right)$ bertujuan untuk mengetahui seberapa besar kemampuan variabel independen menjelaskan variabel dependen, dapat dilihat pada tabel berikut ini:

Tabel 1.4

Koefisien Determinasi

\begin{tabular}{|r|r|r|r|r|}
\hline Model & $\mathrm{R}$ & $\mathrm{R}$ Square & \multicolumn{1}{c|}{$\begin{array}{c}\text { Adjusted R } \\
\text { Square }\end{array}$} & $\begin{array}{c}\text { Std. Error of } \\
\text { the Estimate }\end{array}$ \\
\hline 1 & $.922^{\mathrm{a}}$ & .851 & .846 & 3.72007 \\
\hline
\end{tabular}

a. Predictors: (Constant), kepemimpinan, kompensasi

\section{Sumber: Hasil Olah Data Primer}

Berdasarkan table tersebut diatas yakni model Summary yang menghasilkan nilai $R^{2}$ ( $R$ Square) sebesar 0.851 . Hal ini menunjukan bahwa sebesar $85,1 \%$ Kepemimpinan dan Kompensasi secara simultan (bersama-sama) memang berpengaruh positif terhadap kinerja karyawan sedangkan sisanya sebesar $14.9 \%$ berpengaruh dengan faktor lainnya yang tidak diteliti dalam penelitian ini.

\section{Uji Hipotesis}

\section{a. Uji T}

Untuk mengetahui pengaruh variabel kepemimpinan dan kompensasi secara parsial terhadap kinerja.

\section{1) Kepemimpinan terhadap kinerja}

\section{Tabel 1.5}

Hasil Uji regresi Kepemimpinan terhadap kinerja

\begin{tabular}{|c|c|c|c|c|c|c|}
\hline \multicolumn{7}{|c|}{ Coefficients $^{a}$} \\
\hline \multirow{2}{*}{\multicolumn{2}{|c|}{ Model }} & \multicolumn{2}{|c|}{ Unstandardized Coefficients } & $\begin{array}{l}\text { Standardized } \\
\text { Coefficients }\end{array}$ & \multirow[b]{2}{*}{$\mathrm{T}$} & \multirow[b]{2}{*}{ Sig. } \\
\hline & & B & Std. Error & Beta & & \\
\hline 1 & (Constant) & 3.923 & 2.759 & & 1.422 & .160 \\
\hline & kepemimpinan & .922 & .054 & .913 & 16.989 & .000 \\
\hline
\end{tabular}

a. Dependent Variable: kinerja

\section{Sumber: Hasil Olah Data Primer}

Jika diperhatikan hasil tabel di atas dengan menggunakan perhitungan analisis SPSS Versi 17 , maka nilai $t_{\text {hitung }}$ untuk variabel kepemimpinan (X1) terhadap kinerja karyawan $(Y)$ adalah sebesar 16,989 , sedangkan nilai $t_{\text {tabel }}$ untuk $n=60$ adalah sebesar 1,672. Jadi karena nilai $t_{\text {hitung }}>t_{\text {tabel, }}$ yaitu $16.989>1.672$ dapat disimpulkan bahwa secara parsial variabel kepemimpinan mempunyai 
pengaruh yang positif terhadap kinerja. Nilai probabilitas (signifikansi) $=0,000$ yaitu berada di bawah 0,05 dengan demikian $\mathrm{H}_{\mathrm{a}}$ diterima, dapat disimpulkan bahwa terdapat pengaruh yang positif dan signifikan antara variabel kepemimpinan $(\mathrm{X} 1)$ terhadap kinerja karyawan $(\mathrm{Y})$, karena nilai probabilitasnya lebih kecil dari 0,05 .

\section{2) Kompensasi terhadap kinerja}

Tabel 1.6

Hasil Uji regresi Kompensasi terhadap kinerja

\begin{tabular}{|c|c|c|c|c|c|c|}
\hline \multicolumn{7}{|c|}{ Coefficients $^{a}$} \\
\hline \multirow{2}{*}{\multicolumn{2}{|c|}{ Model }} & \multicolumn{2}{|c|}{ Unstandardized Coefficients } & $\begin{array}{l}\text { Standardized } \\
\text { Coefficients }\end{array}$ & \multirow[b]{2}{*}{$\mathrm{t}$} & \multirow[b]{2}{*}{ Sig. } \\
\hline & & $\mathrm{B}$ & Std. Error & Beta & & \\
\hline 1 & (Constant) & 5.894 & 3.062 & & 1.925 & .059 \\
\hline & kompensasi & .882 & .060 & .887 & 14.659 & .000 \\
\hline
\end{tabular}

a. Dependent Variable: kinerja

Jika diperhatikan juga hasil tabel di atas dengan menggunakan perhitungan analisis SPSS Versi 17, maka nilai $t_{\text {hitung }}$ untuk variabel kompensasi (X2) terhadap kinerja karyawan $(Y)$ adalah sebesar 14,659, sedangkan nilai $t_{\text {tabel }}$ untuk $\mathrm{n}=60$ adalah sebesar 1,672. Jadi 14,659> 1,672 dapat disimpulkan bahwa secara parsial variabel kompensasi mempunyai pengaruh yang positif terhadap kinerja. Nilai probabilitas (signifikansi) $=0,000$ yaitu berada di bawah 0,05 , dengan demikian $\mathrm{H}_{\mathrm{a}}$ diterima, dapat disimpulkan bahwa terdapat pengaruh yang positif dan signifikan antara variabel kompensasi (X2) terhadap kinerja karyawan $(\mathrm{Y})$, karena nilai probabilitasnya lebih kecil dari 0,05.

b. Uji F

Untuk menguji pengaruh kepemimpinan dan kompensasi secara simultan terhadap kinerja, dapat digunakan uji statistik F (uji F), dengan menggunakan taraf signifikansi $5 \%(0,05)$.

Tabel 1.7

Hasil Uji F

ANOVA $^{b}$

\begin{tabular}{|rr|r|r|r|r|r|}
\hline Model & & Sum of Squares & df & Mean Square & \multicolumn{1}{c|}{ F } & \multicolumn{1}{c|}{ Sig. } \\
\hline 1 & Regression & 4500.017 & 2 & 2250.008 & 162.585 & $.000^{\mathrm{a}}$ \\
& Residual & 788.819 & 57 & 13.839 & & \\
& 5288.836 & 59 & & & \\
\hline
\end{tabular}

a. Predictors: (Constant), kepemimpinan, kompensasi

b. Dependent Variable: kinerja

Sumber: Hasil Olah Data Primer 
Dari Hasil tabel diatas dapat dijelaskan bahwa pengaruh antara variabel kepemimpinan (X1) dan Kompensasi (X2) secara simultan terhadap kinerja karyawan (Y) Positif dan sangat signifikan karena nilai $\mathbf{F}_{\text {hitung }}>$ nilai $\mathbf{F}_{\text {tabel }}$ yaitu $162.585>3.153$ sehingga Ha diterima.

\section{G. Analisis Hasil Penelitian dan Pembahasan}

\section{Analisis Deskriptif}

Penilaian Kepemimpinan dilakukan berdasarkan indikator -indikator yang telah ditetapkan. Masing-masing sub indikator terdiri dari beberapa pernyataan yang menggambarkan kepemimpinan, yang dideskripsikan sebagai berikut :

a. Kepemimpinan Pengarah (Directive Leadership)

Berdasarkan hasil penelitian menggunakan kuesioner yang diberikan kepada pekerja proyek PT. Airtas Rekacipta lluminasi, Kepemimpinan pengarah umumnya sudah cukup baik, yaitu sebagian besar responden memperoleh kejelasan arahan dalam bekerja dan pemimpin dianggap jelas dalam memberikan hasil pekerjaan yang ingin dihasilkan.

b. Kepemimpinan Pendukung (Supportive Leadership)

Berdasarkan hasil penelitian menggunakan kuesioner yang diberikan kepada pekerja proyek PT Airtas Rekacipta lluminasi, Kepemimpinan pendukung umumnya sudah cukup baik, yaitu sebagian besar responden mengisyaratkan bahawa Pemimpin mereka memiliki sikap yang ramah, dan kehadiran pemimpin dapat meningkatkan semangat bekerja.

c. Kepemimpinan Partisipatif (participative leadership)

Berdasarkan hasil penelitian menggunakan kuesioner yang diberikan kepada pekerja proyek PT Airtas Rekacipta Iluminasi, Kepemimpinan Partisipatif umumnya sudah cukup baik, yaitu sebagian besar responden mengisyaratkan bahawa Pemimpin mereka memberi kebebasan dalam hal mengemukakan saran dan pendapat, dan juga pemimpin dapat menciptakan suasana kerja yang baik, sehingga dapat meningkatkan etos kerja.

d. Kepemimpinan Berorientasi Prestasi (Achievement-Oriented Leadership)

Berdasarkan hasil penelitian menggunakan kuesioner yang diberikan kepada pekerja proyek PT Airtas Rekacipta lluminasi, Kepemimpinan Berorientasi Prestasi umumnya sudah cukup baik, yaitu sebagian besar responden mengisyaratkan bahawa Pemimpin mereka memberi bonus dan pujian apabila mereka menyelesaikan tugas dengan baik dan sesuai target yang direncanakan, artinya kepemimpinan seperti ini mendorong untuk karyawan lebih berprestasi dan lebih meningkatkan kinerja.

Penilaian Kompensasi dilakukan berdasarkan indikator -indikator yang telah ditetapkan. Masing-masing sub indikator terdiri dari beberapa pernyataan yang menggambarkan Kompensasi, yang dideskripsikan sebagai berikut :

a. Kesesuaian Upah Perusahaan dengan Peraturan Pemerintah

Berdasarkan hasil penelitian menggunakan kuesioner yang diberikan kepada pekerja proyek PT Airtas Rekacipta lluminasi, sebagian besar responden memberikan respon bahwa upah yang diterima sudah sesuai dengan UMR dan menganggap upah bekerja di perusahaan lain yang sejenis adalah kisarannya sama. Artinya menurut responden upah di Perusahaan Arilum besarnya sebanding dengan upah bekerja di perusahaan lain.

b. Imbalan dan Bonus yang layak dan adil

Berdasarkan hasil penelitian menggunakan kuesioner yang diberikan kepada pekerja proyek PT Airtas Rekacipta lluminasi, sebagian besar responden memberikan pernyataan bahwa upah yang diterima layak dan adil, artinya upah yang diterima antara sesama rekan kerja satu dan lainnya dirasakan 
sudah adil. Sistem Kompensasi di perusahan ini sudah cukup baik karena di Perusahaan ini memberikan bonus akhir proyek kepada karyawan.

c. Kesesuaian Upah dengan harapan

Berdasarkan hasil penelitian menggunakan kuesioner yang diberikan kepada pekerja proyek PT Airtas Rekacipta lluminasi, menggambarkan cukup seimbang proporsi antara responden yang memberikan pernyataan bahwa upah yang diterima sesuai dengan harapan dan tidak sesuai dengan harapan. Sebagian responden, sekitar $45 \%$ masih banyak yang mengatakan upah nya belum bisa memenuhi kebutuhan hidup dan belum sesuai dengan harapan mereka.

Penilaian Kinerja Karyawan dilakukan berdasarkan indikator -indikator yang telah ditetapkan. Masing-masing sub indikator terdiri dari beberapa pernyataan yang menggambarkan Kompensasi, yang dideskripsikan sebagai berikut :

a. Kualitas

Berdasarkan hasil penelitian menggunakan kuesioner yang diberikan kepada pekerja proyek PT Airtas Rekacipta lluminasi, sebagian besar responden memberikan pernyataan bahwa mereka ingin bekerja mengahsilkan kualitas pekerjaan yang baik. Indikator kinerja dari aspek kulaitas ini sudah cukup baik.

b. Kuantitas

Berdasarkan hasil penelitian menggunakan kuesioner yang diberikan kepada pekerja proyek PT Airtas Rekacipta lluminasi, sebagian besar responden memberikan pernyataan bahwa mereka ingin bekerja mengahsilkan pekerjaan yang banyak, dan mencapai target quantity yang diinginkan kepala proyek. Indikator kinerja dari aspek kuantitas ini sudah cukup baik.

c. Ketepatan waktu

Berdasarkan hasil penelitian menggunakan kuesioner yang diberikan kepada pekerja proyek PT Airtas Rekacipta lluminasi, sebagian besar responden memberikan pernyataan bahwa mereka ingin bekerja selesai tepat waktu, dan tidak ingin menunda-nunda pekerjaan, walaupun demikian masih ada sebagian karyawan yang masih suka menunda-nunda pekerjaan. Indikator kinerja dari aspek ketepatan waktu ini sudah cukup baik.

d. Efektivitas

Berdasarkan hasil penelitian menggunakan kuesioner yang diberikan kepada pekerja proyek PT Airtas Rekacipta lluminasi, sebagian besar responden memberikan pernyataan bahwa mereka bekerja menggunakan alat dan cara yang memudahkan dan mempercepat pekerjaan, hal ini dilakukan agar memperoleh hasil pekerjaan yang baik dan cepat. Sebagian besar responden tidak ada yang santai-santai dalam bekerja. Indikator kinerja dari aspek efektivitas ini sudah cukup baik.

e. Kemandirian

Berdasarkan hasil penelitian menggunakan kuesioner yang diberikan kepada pekerja proyek PT Airtas Rekacipta lluminasi, sebagian besar responden memberikan pernyataan bahwa mereka bisa bekerja dengan baik tanpa diawasi. Hal ini menggambarkan bahwa kemandirian kerja karyawan di dalam perusahaan ini sudah cukup baik.

f. Komitmen kerja

Berdasarkan hasil penelitian menggunakan kuesioner yang diberikan kepada pekerja proyek PT Airtas Rekacipta lluminasi, sebagian besar responden memberikan pernyataan bahwa mereka bekerja semaksimal kemampuan yang mereka miliki, namun cukup besar responden sekitar $58 \%$ menyatakan tidak ingin memajukan perusahaan, artinya mereka hanya bekerja sesuai kemampuan tanpa ada niat untuk kemajuan perusahaan. Sebagian besar responden juga tidak ikut bekerja hingga akhir proyek. 


\section{H. Kesimpulan}

1. Terdapat pengaruh positif dan signifikan antara Kepemimpinan (X1) terhadap Kinerja Karyawan ( $\mathrm{Y}$ ). Koefisien regresi positif yang didapat sebesar 0,922 dengan kontribusi sebesar $83,3 \%$ dan nilai $\mathbf{t}_{\text {hitung }} 16.989$ dengan signifikansi t sebesar 0,000 . Model Regresi sederhana $Y=3.923+0.922 X_{1}$.

2. Terdapat pengaruh positif dan signifikan antara Kompensasi (X2) terhadap Kinerja Karyawan $(\mathrm{Y})$. Koefisien regresi positif yang didapat sebesar 0,882 dengan kontribusi sebesar $78.7 \%$ dan nilai $\mathbf{t}_{\text {hitung }} 14.659$ dengan signifikansi $\mathrm{t}$ sebesar 0,000 . Model Regresi sederhana $Y=5.894+0.882 X_{2}$.

3. Terdapat pengaruh positif dan signifikan secara simultan antara Kepemimpinan (X1) dan Kompensasi (X2) terhadap Kinerja Karyawan (Y). Koefisien regresi positif yang didapat Kepemimpinan 0,619 dan Kompensasi 0,362 dengan kontribusi sebesar $85,1 \%$ dan nilai $\mathbf{F}_{\text {hitung }} 162.585$ dengan signifikansi f sebesar 0,000. Model Regresi Berganda $Y=2,721+0,619 X_{1}+0,326 X_{2}$.

\section{Daftar Pustaka}

Arikunto, 2006, Prosedur Penelitian Suatu Pendekatan Praktik, RenikaCipta, Jakarta

Bangun, Wilson, 2012, Manajemen Sumber Daya Manusia. Erlangga, Jakarta.

Gibson, J.L.2003, Struktur Organisasi dan Manajemen, Erlangga, Jakarta.

Handoko, T. Hani. 2001. Manajemen Personalia dan Sumber Daya Manusia, Andi, Yogyakarta.

Haryadi, sarjono dan Winda, Julianita, 2011, SPSS VS LISREL, sebuah pengantar aplikasi untuk riset, Salemba Empat, Jakarta.

Hasibuan, Malayu, 2006, Manajemen Sumber Daya Manusia, Edisi Revisi, PT. Bumi Aksara. Jakarta.

Irianto, Jusuf 2001, Tema - tema pokok Manajemen Sumber Daya Manusia, Insan cendekia, Jakarta.

Jackson, Susan E, Randall S. Schuler, Steve Werner, 2011, Pengelolaan Sumber Daya Manusia, Edisi Kesepuluh (Terjemahan), Salemba Empat, Jakarta.

Kreitner dan Kinicki, 2005, Perilaku Organisasi, Salemba empat, Jakarta

Kartini, Kartono, 2005, Pemimpin dan Kepemimpinan, PT. Raja Grafindo Persada, Jakarta.

Kaswan 2012, Manajemen Sumber Daya Manusia untuk keunggulan bersaing organsasi, Grha IImu, Yogyakarta.

Mangkunegara, A.A. Anwar Prabu, 2005, Manajemen Sumber Daya Manusia Perusahaan. PT. Remaja Rosda karya, Bandung.

Moheriono, 2012, Pengukuran kinerja Berbasis kompetensi, Raja Grafindo Persada, Jakarta.

Mulyadi, 1997, Akuntansi Manajemen Edisi 2, Bagian Penerbitan Sekolah Tinggi IImu Ekonomi YKPN, Yogyakarta.

Poltak Sinambela, Lijan, 2012, Kinerja pegawai, Graha IImu, Yogyakarta.

Rivai, Veithzal dan Jauvani S., Ella, 2010, Manajemen Sumber Daya Manusia Untuk Perusahaan, Raja Grafindo Persada. Jakarta. 
Robbins, Stephen P., 2003, Perilaku Organisasi, PT. Indeks Kelompok Gramedia, Jakarta.

Robbins, 2006, Organizational Behaviour, Tenth Edition. Edisi Bahasa Indonesia, PT. Indeks Kelompok Gramedia, Jakarta.

Siagian, Sondang, 2010, Teori dan praktek Kepemimpinan, Rineka Cipta, Jakarta.

Simamora, Henry, 2006, Manajemen Sumber Daya Manusia, Penerbitan STIE YKPN, Yogyakarta.

Solihin, ismail, 2009, pengantar manajemen, Erlangga, Jakarta.

Sugiyono, 2003, Metode Penelitian Administrasi, Alfabeta, Bandung.

Sugiyono, 2010, Metode Penelitian Bisnis, Alfabeta, Bandung.

Sunyoto, Dadang, 2013, Manajemen Sumber Daya Manusia, CAPS, Yogyakarta.

Sutrisno, Edy, 2009, Manajemen sumber Daya manusia, Kencana, Jakarta.

Werther, William B. \& Keith Davis, 1996, Human Resources And Personal Management International Edition, McGraw-Hiil, Inc., USA.

Wibowo, 2013, Manajemen Kinerja, Raja Grafindo Persada. Jakarta.

Wibowo, 2013, Perilaku Dalam Organisasi, Raja Grafindo Persada. Jakarta.

Yukl Gary, 1998, Kepemimpinan dalam organisasi, Prenhallindo, Jakarta http://file.upi.edu/Direktori/FIP/JUR. PEND. LUAR SEKOLAH/1945050319710 91.Muhammad Kosim Sirodjudin/Definisi Dan Teori Kepemimpinan.pdf, diakses tanggal 10 Juni 2014.

http://www.ut.ac.id/html/suplemen/adpu4334/w2 111 1.htm, diakses tanggal 14 Juni 2014.

http://teori-mgt-ian.blogspot.com/2011/01/pengertian-kinerja_20.html, diakses tanggal 16 Juni 2014.

http://all-about-theory.blogspot.com/2010/03/kompensasi.html, diakses tanggal 16 Juni 2014. 